Tér és Társadalom 21. évf. 2007/4. 1-20. p.

Tér és Társadalom

XXI. évf. 2007 - 4: 1-20

\title{
A KÍNAI VÁROS
}

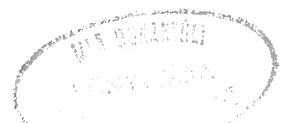

\author{
(The Chinese City)
}

\section{ENYEDI GYÖRGY}

\begin{abstract}
Kulcsszavak:
endogén városfejlödés tervezett és ellenörzött városnövekedés „bolyongö" népesség

A tartósan gyorsan növekedö és felzárkózó kínai gazdaság, ennek látványos városföldrajzi következményei - hatvan városnak van l milliónál több lakosa-világszerte hatalmas szakmai érdeklódést vált ki. $E$ tanulmány fö kérdése: a mai kínai városfejlödés mennyire endogén, az évezredes kínai urbanizáció hagyományait folytató folyamat, s mennyire simul be a globalizáció városfejlödési folvamataiba?

A vizsgálat következtetése, hogy a kinai urbanizáció endogén - nem modell-követó. Kína a világ egyetlen folyamatos - több mint háromezer éves - urbanizációjának térsége; az urbanizáció gazdasági forrása, szervezeti kerete, a városirányitás, a belsó társadalmi szervezet mindvégig különbözött bármely más urbanizációs térségétól. A jelen városnövekedés is sajátos: üteme fékezett (a városi népességarány mindössze 35-40\%), a városhálózat arányosan bövill (eltéröen bármely más fejlödö vagy felzárkózó országétól), a falu-város vándorlás szigorian (ha nem is mindig eredményesen) ellenörzött. A túlnépesedés és szegénység falura zárt; a falusi munkaerö-feleslegnek a városi gazdaságba történö fokozatos átvezetése középtávon még fenntarthatja a gyors gazdasági növekedést, ám a vidéki fejlesztések elmaradása hosszú távon társadalmi-gazdasági konfliktusok forrása lehet.
\end{abstract}

\section{Bevezetés}

Kína egészen sajátos szerepet játszik a városi világ globális elterjedésében. Egyfelől a városnövekedés igen látványos, üteme különösen gyors - ma mintegy félmilliárd városlakó él Kínában, több mint bármely más globális régióban (jóval több, mint egész Európában). Nemcsak néhány mega-város felduzzadásáról van szó a Föld 15 legnépesebb városa közül 2001-ben csak kettő volt Kínában, Beijing és Shanghai (ez volt a helyzet 1950-ben is), hanem egy erős nagyvárosi rendszer kibontakozásáról: hatvan városnak van egy milliónál több lakosa. Másfelöl, Kína továbbra is falusi ország: a városi népességnek a teljes népességhez viszonyított aránya legfeljebb $40 \%$ - mint hazánkban az ipari társadalom kibontakozása elött, a 20. század elején volt'. Egyfelől Kína a legrégebbi folyamatos (mintegy háromezer éves) urbanizảció térsége - az antik urbanizáció a Földközi-tenger medencéjében évszázadokra megszakadt ${ }^{2}$, másfelől jelenleg a legrohamosabb átalakulás színtere, városaiban több modern urbanizációs szakasz torlódik egymásra. Az államszocialista rendszer maoista változata évezredes városi hagyományokat és szerkezeteket tördelt össze, de nem tüntetett el teljesen. Ösi hagyományok, a Mao-i rendszer szabályozási elemei és a piaci reform, az ellenőrzött piacgazdaság új funkciói, városmorfológiảja és társadalmi rétegződése fonódnak össze sajátos eleggyé. Érthető a városföldrajz roppant érdeklődése a kínai urbanizáció iránt: a témáról különszámokat jelentetett meg az Urban Geography (kétszer is: 1995-ben és 2005-ben), az 
Urban Studies (2002), a Progress in Planning (2004) etc. A kínai urbanizáció nem marad a Kína-kutatók szakmai érdeklődési körén belül: a világ urbanizációs folyamatai fordulnak most új irányokba, s ebben a kínai urbanizáció, már méreténél és sajátos mechanizmusánál fogva is, kitüntetett szerepü.

Egy rövid tanulmány csak valaminö summázatra vállalkozhat. A fö kérdés, melyre választ keresünk, a következö: a mai kínai városfejlódés mennyire endogén, az évezredes urbanizáció hagyományait folytató folyamat, s mennyire simul be a globalizáció városfejlódési folyamataiba? Az a hipotézisünk, hogy sajátos, endogén folyamatról van szó, melynek a globális nagyvárosokra jellemzö külső, morfológiai jegyei - a felhőkarcolóktól a karaoke-bárokig - mögött sajátos, egyedi társadalmi mechanizmusok, szerkezetek, városfejlesztő energiák húzódnak. Az kétségtelen, hogy korábban a kínai városhálózat egésze soha nem nyílt így ki külső urbanizációs hatások befogadására - ám úgy véljük, a kínai társadalom tradicionális ereje most is képes lesz az új hatások beolvasztására, „kínaizálására”. A fö kérdés megválaszolására az alábbi vizsgálati témákat tekintjük át: 1) történelmi gyökerek a) a kínai urbanizáció múltja a modern urbanizáció kezdete elött; b) a modern urbanizáció kezdetei, 1949-ig; 2) A szocialista Kina városfejlỏdése a) a Mao-i államszocializmus várostervezése b) a jelen: a piaci reform évtizedeinek hatása a városfejlödésre. A mai kínai városfejlődés vizsgálatának fö szempontjai: a városnövekedés forrásai; a növekedés tervszerủ korlátozása-szabályozása; a városhálózat formálódása. Nem térünk ki e dolgozatban a városi társadalom rétegződésének, a városmorfológia új elemeinek vizsgálatára.

\section{A történelmi gyökerek}

\section{Háromezer éves urbanizáció}

A kínai urbanizáció Észak-Kínában gyökeredzik, kezdetei a Shang dinasztia (i.e. 1766-1122) és a Chou dinasztia (i.e. 1122-256) idejére tehetök. Az ezt követő 450-500 év alatt megjelent a városok egész sora, míg a T'ang dinasztia idején (618-917) egy teljesen integrált városrendszer fejlödött ki. A városi népesség a teljes lakosság mintegy $10 \%$-át tette ki - annyit, mint a 19-20. század fordulóján. A középkori urbanizáció folyamatosan fejlődött, a kis- és középvárosi hálózat erősödésével - Marco Polo irigykedve bámulta a középkori Európához viszonyítva fejlett s gazdag kínai városokat. A középkorban és az újkor elején Kína volt a világ legfejlettebb urbanizációs térsége. A mongol invázió e fejlődést megakasztotta, ám az urbánus fejlódés a Ming korszak (1368-1644) második felében újra kezdődött.

Több mint háromezer év urbanizációja természetesen számos időbeni és térbeni (geográfiai) változatot produkált. Mégis egységes, a világon egyedülálló folyamat: az egész hatalmas területet azonos típusú gazdálkodás és szocio-kulturális rendszer jellemezte, és egységbe foglalta a központosított birodalmi politikai rendszer; a kínai kultúra és politikai rendszer is egyedülálló volt az emberiség történetében. 
A kínai birodalom földrajzi bölcsője a Sárga folyó középső folyása és e szakasz mellékfolyói - innen terjedt szét a birodalom az észak-kínai síkságon. A birodalom térbeli terjeszkedését nyomon követhetjük a megyeszékhelyek megjelenése nyomán. E székhelyek eredetileg katonai-kőzigazgatási támaszpontok voltak, és jelezték a mezőgazdasági mủvelés és a kínai civilizáció előnyomulását. Ez az előnyomulás tervezett és szervezett folyamat volt, a Jang Ce völgyön és a délkeleti tengerparton folytatódott - jóval később került sor a mai Dél-Kínára. A 14. század második felére alakult ki teljes egészében a kínai birodalom, a Nagy Faltól délre és Tibettől keletre (Eisenstadt-Shachar 1983).

A kínai társadalmi-politikai rendszer alapvonásai időszámításunk körül alakultak ki, és a 19. század végéig maradtak meg. Ez a rendszer erösen központosított volt: a császár és az írástudók (bürokraták) koalíciója irányította. A pre-modern Kínában nem létezett európai értelmủ feudalizmus, nem volt nagybirtokos osztály, az egyház nem vált világi hatalommá. ${ }^{3}$ A kínai tradíció erősen e-világi: az egyén kötelességeit és felelösségét hangsúlyozza a családjával, kisebb (települési) közösségével s a birodalom szolgálatával kapcsolatban. A birodalom szolgálata nemcsak engedelmességet, hanem a hatalom támogatását, a birodalmi felelősségben való részvételt is jelentette.

$\mathrm{Az}$ írástudó bürokraták kapcsolták össze a birodalmi központot a társadalom szélesebb rétegeivel. A bürokrata elitet a Konfucius-i hivatalnok vizsgát tettek csoportja alkotta ${ }^{4}$. E réteg közös kulturális hátterét éppen a hivatalnok iskolák és vizsgák követelménye adta. Külön nyelvet is beszéltek, megkülönböztetve a helyi nyelvjárásoktól, a mandarin nyelvet, amely ma Kína hivatalos nyelve. A hivatalnoki elit elvben valamennyi társadalmi csoportból kikerülhetett, még a parasztságból is, valóságban a gentry (köznemes) volt a fö rekrutációs bázis. Az írástudó elitből kerülttek ki a tudomány és kultúra múvelöi is. A hatalmi központtal való kapcsolat felett az elit monopol-joggal rendelkezett; ez azonban nemcsak az engedelmességen, hanem a szolidaritáson is alapult.

A konfuciánus ideológia az eliten kívüli társadalmat négy, hierarchikus csoportra osztotta. Ezek: a tudósok, a parasztok, a kézmủvesek és a kereskedők. A legnagyobb megbecsülést a tudósok élvezték; a feltételezés szerint csak ök ismerték és gyakorolták a helyes életformát. A parasztok feladata az élelem biztosítása volt. A kereskedôket nem becsülték sokra, úgy vélték, nem feltétlenül szükséges a tevékenységük, $\mathrm{s}$ életmódjuk sem példás. A valóságban persze sokkal összetettebb volt a társadalmi szerkezet, mint ahogyan a konfucianusi elképzelés leírta.

A társadalmi osztályok nem voltak homogének. A felsỏ osztályok megoszlottak a születés (családi eredet), a tudás, a politikai hatalom, az alsó osztályok a foglalkozás és a vagyon szerint. A felső osztályok három, részben egymást átfedő kategóriára oszlottak: arisztokrácia, az írástudó gentry, a hivatalnokok. Az arisztokrácia csak a 10. század végéig volt jelentős, utána gyakorlatilag eltünt. A legfontosabb elitcsoport az írástudó gentry - vidéki birtokos - volt, a földhöz kötött parasztság és a hivatalnoki kereskedő réteg közé illeszkedve. Mint említettük, a paraszt nem feudális elöirások 
miatt volt földhöz kötve - a parasztok szabadon adhattak-vehettek földet -, inkább a falusi túlnépesedés, a földhiány miatt.

Az alsó néprétegeknek is volt belsỏ hierarchiája. Ilyen volt a vagyoni helyzet. Az alsó- és felső osztályok közötti mobilitást elsősorban a tanulás, a konfuciánus oktatás biztosította. Ez az út hivatalosan zárva volt a kereskedők elött, ám vagyonos kereskedők azért tudtak tanulási lehetőséget biztosítani fiaiknak, illetve fơldvásárlással bejutni a gentryk közé. A hivatalnokká váláshoz vizsgák kellettek, de azért vásárolni is lehetett hivatalt, $\mathrm{s}$ a császár is adományozhatott - magas - hivatalokat. Volt még egy kasztszerủ alsó réteg, ahonnan nem volt felemelkedés (mivel haszontalannak minősítették őket: rabszolgák, szolgák, prostituáltak, komédiások, koldusok). Ez a társadalmi szerkezet átszőtte az egész gazdálkodási rendszert (Balazs 1964).

A kínai gazdaság kezdetektől a mezógazdaságra alapozódott, melyet jól szervezett kereskedelmi rendszer egészített ki. A nagyon intenzív öntözéses gazdálkodásban a vízforrások feletti ellenőrzés volt a központi probléma. Az évi többszöri termés nagy népességet volt képes eltartani, de az aszályok, árvizek kockázatossá tették a termelést. A csatornák és árvízi töltések karbantartása volt a központi adminisztráció fö feladata: ezt nem lehetett csak helyben, csupán a falvakban szabályozni.

A mezögazdaság fö termelési egysége a paraszt-falu volt, melynek szervezete, sajátosságai roppant stabilitást mutattak (évezredeken át). A hagyományos tulajdonosi egység a család, amely vagy bérelte a földet (az államtól), vagy saját tulajdonában volt. A 7. századtól kezdve minden házaspárnak azonos méretü földterület járt. Ez a terület kiegészült, ha gyerekek születtek, vagy például magatehetetlen rokont fogadtak be, csökkent elhalálozás vagy családból kilépő felnőtt gyerekek házassága esetén. Gyakorlatilag minden évben ủjraosztották a földeket, a Háztartási Adattár alapján!

A gentry és a hivatalnokok földtulajdonlása kevésbé volt szabályozott. A vidéki nemes földjét ajándékba kapta a császártól, és örökölhető volt, a hivatalnoknak a hivatalához járt földterület használat - mindkét földhasználat adómentes volt.

A magas eltartó képességü mezőgazdaság, mely messze túllépett a paraszti önellátáson, a fejlett kereskedelmi rendszer, a földtulajdon adás-vétele (a 3. századtól!), a kultúra és igazgatási-ellenőrző rendszer sokfélesége, a társadalmi rétegződés viszonylag fejlett városrendszert hozott létre. A régészeti leletek tanúsága szerint az i.e. 2. évezred közepén már fejlett városi civilizáció volt a Sárga folyó mentén. Említettük, hogy a megmủvelt földterület terjeszkedésével terjedt szét a városrendszer a birodalom északi magterületéröl - ahogyan megkezdỏdött a földmüvelés, megjelentek a katonai-közigazgatási központok, védelmet nyújtva, a központ (a föváros) ellenőrzését és adóbegyủijtését biztosítva, de fontos igazgatási szolgáltatásokat is nyújtva, pl. a földbirtok-viszonyok szabályozásával, az öntözés megszervezésével. A megyeközpontok nyújtottak városi szolgáltatásokat a falvak népességének, $\mathrm{s}$ föléjük épült az egész városi hierarchia, a tartományi székhelyeken át a császári székvárosig. A városokat fal vette körül - a kínai „Ch'eng” szó egyszerre jelent falat és várost - védelmi céllal s hatalmi szimbólumként is. A kínai urbanizáció indítója tehát a falu - a mezőgazdaság - terjedése, a kereskedelem megjelenése és erősödése volt. A kereskedelem, a piacok mérete és specializációja tájanként és 
időszakonként változott. Kettős városhierarchia alakult ki: az igazgatási és a kereskedelmi (gazdasági); más, pl. politikai, etnikai, kulturális hierarchiák nem formálódtak. A kínai urbanizáció sokat köszönhet a paraszti társadalom egyenjogúságának, teljes jogú részvételének a kereskedelemben, a városi gazdasági funkciók használatában és mủködtetésében.

A városhierarchia csúcsán természetesen a császári székhely-föváros állt. Hosszú időn keresztül a fỏváros változott, hol geopolitikai viszonyokhoz, hol a gazdasági fejlödés földrajzi változásaihoz, hol egyszerủen a császári akarathoz alkalmazkodva. A 10-13. század között a kínai egység felbomlott, több hasonló jelentöségü regionális központ töltött be föváros szerepet. A 13. században a Yüan dinasztia helyreállította a központosított birodalmi rendszert, $\mathrm{s}$ helyezte a császári fỏvárost Beijingbe, mely kisebb-nagyobb megszakításokkal, 800 éve föváros - de ne feledjük, hogy ez a kínai urbanizáció történetének csak egynegyede. Egy 150 éves periódust leszámítva, egyetlen fỏváros sem telepedett a tengerpartra, mely kifejezte a birodalom befelé fordulását: elsỏdleges cél a hatalmas belső szárazföldi terület ellenörzése volt.

Az urbanizáció kezdeti szakaszán a helyi központok (megyeszékhelyek) egyidejüleg töltöttek be adminisztratív (pl. központi adószedési) és gazdasági (kereskedelmi) funkciókat. Érdekes, hogy a területi terjeszkedés és a népesség növekedése ellenére a helyi központok száma változatlan maradt; ahogyan új megyék s székhelyek szerveződtek, úgy csökkent a régi igazgatási központok száma, $\mathrm{s}$ vontak össze megyéket. Érthetően szétvált a városok igazgatási és gazdasági szerepkơre: az igazgatási központokon kívül számos, csak kereskedelmi szerepű város jött létre. E szétválás is erősitette a centralizációt, nehezítette a regionális igazgatási és gazdasági elit önállósodását, szövetségét a fövárossal (birodalmi központtal) szemben.

$\mathrm{Az}$ igazgatási és a kereskedelmi város belső szerkezete különbőzỏ volt. Az igazgatási város tervezett alaprajzú volt; kifejezett vallási felfogást és a központosítás szimbólumát. A várost négyszögű fal vette körül; az utcák É-D-i, illetve $\mathrm{K}-\mathrm{Ny}-\mathrm{i}$ irányban futottak, mindkét irányban kilenc-kilenc utca (a kilenc büvös szám volt). A város központi részét is fal vette körül, azon belül voltak a hatalmi-igazgatási intézmények és a nemesség lakóterületei, azon kívül pedig a kereskedelmi, kisipari övek, az egyszerú emberek lakóterületei. A déli irány volt ,jó", magasabb presztízsü: a városfal déli részén volt a fơbejárat, a császári vagy kormányzói palotától délre helyezkedtek el a kormányzati épületek, s mindig északra a konfucianizmus által kevésre tartott kereskedelmi övezetek (városi piac). A kereskedelmi város nem volt fallal kerített, nem volt szabályos alaprajzú. Az utcák futását a felszíni viszonyok és a belső funkcionális övek elhelyezkedése szabta meg. A belső városmorfológiát a gazdaság ésszerüsége formálta: a közlekedés, szállítás feltételei, az egyes lakónegyedek vonzó - vagy elönytelen - környezete, az ingatlan árak stb. ÉszakKínában, ahol a kínai urbanizáció kezdetei bontakoztak ki, a tervezett városok, DélKínában, ahol a városok többségét már a gazdasági funkciók hozták létre, a spontán módon fejlődött városok voltak többségben. 
A kínai város további sajátossága, hogy soha nem rendelkezett valóságos autonómiával. Ahogy Mote írta: „a kínai városban nincsenek városi polgárok, nincs városi közösség s identitás, nincs önkormányzat, és soha nem vált el kormányzása a vidékétől" $(1977,114)$. A központi kormányzat nevezett ki minden közigazgatási vezetőt, a városét, de a kerületekét is, nem volt választott testület - következésképpen városháza vagy városi tanács sem. Ugyanakkor a gazdasági-kereskedelmi szerveződés (a kereskedelmi céhek) erös volt, de ez nem érintette a politika és igazgatás szféráját. A városi igazgatás része volt a regionális igazgatásnak, tehát nem különült el a falutól - ismét jelentős különbség Európától. A régió adminisztrációja alá egyként tartozott falu és város; csak a császári főváros volt kivétel, melyet a központi kormány igazgatott. A városi gazdaság állami ellenőrzése - rögzített árak, kamatláb, termelési mennyiségek megszabása, a kereskedők pontos könyvelésének ellenőrzése stb. - is évezredes hagyományú.

A kereskedelmi céhek általában kicsinyek voltak, tagjaik ismerték egymást, rendezö elvük a tagok közös földrajzi eredete volt. Erős volt a belső szolidaritás, de nem voltak elég erősek, hogy érdekeiket az adminisztrációval szemben érvényesíthették volna - ez nem is illett a konfuciánus hagyományokba. Függőségüket erősítette, hogy a kereskedelmi terek, mühelyek, a városi földterület állami tulajdonban voltak. A gazdag kereskedők számára a termöföld vagy a hivatali rang vásárlása jelentette az elömenetelt.

A kínai város tehát - szemben nem csak az európai, de a japán várossal is - bármilyen gazdag és jól szervezett volt, soha nem vált a központi kormányzattól független központtá, és mivel nem alakult ki a polgári osztály és a polgári ideológia, nem jött létre a városi identitás polgári értelme, a város még a központi hatalom megroppanása esetén sem volt önálló tényező, nem játszhatott szerepet a dinasztiák s helyi hadvezérek hatalmi viaskodásában.

A kínai urbanizáció első, a 19. század végéig tartó három évezredes szakaszát - a rengeteg történelmi, hatalmi, földrajzi fordulat mellett - nagy stabilitás is jellemezte, számos alapvonása tartósnak bizonyult, és szerepet játszott az eddig rövid múltú modernizáció formálódásában is.

Az első alapvonás, hogy folyamatosan erôs, világos funkciójú városhálózat alakult ki, mely e hatalmas területü birodalmat általában egységesen irányítani volt képes. A lakosság túlnyomó részben falun élt, a kínai civilizáció ennek ellenére erősen városi civilizáció. A városok erejét és hatékony működését az öntözéses mezőgazdaság nagy élelmiszer bősége is biztosította: jó színvonalon volt képes ellátni a mezőgazdasággal egyáltalán nem foglalkozó városlakókat. Az öntözéses gazdálkodás fenntartása is igényelte az erős - vízelosztással, árvízvédelemmel, ma úgy mondanánk, a mezőgazdaság logisztikájával foglalkozó - városi adminisztrációt. A városok nem csak piaci funkciókat és irányító-igazgatási funkciókat töltöttek be, de sok technikai újitást is bevezettek. Jól ismert, milyen ipari újitásokkal előzték meg sok évszázaddal a kínai városok Európát, a puskaportól az iránytüig. Erre hivatkozva nevezi Gernet (2005) egyenesen ipari civilizációnak a kínai civilizációt. A városhálózatot tehát nem az ipari forradalom vagy más típusú modernizáció hozta 
létre (bár a hálózat egyes elemeit természetesen jobban kiemelte), hanem évezredeken át fejlödött, $\mathrm{s}$ ezzel a modernizáció kezdetén, az alacsony városi népességarány ellenére Kína alapvetően különbözött a később „harmadik világ”-nak nevezett, elmaradott országoktól.

A másik sajátosság, hogy a városhálózat befelé fordult; a Kínai Birodalom (és városhálózata) a szárazföld belsejéböl kezdett kifejlödni, s a városok fö hatalmi feladata a kínai terület együtt-tartása, ellenörzése volt. Kína igen hosszú tengerparttal rendelkezik, ennek ellenére a 19. századig jelentős tengerparti városa nem volt, Kína külsỏ expanziót nem tervezett. Ez a ,hátat fordítás” a tengernek s ezzel a külvilágnak a kínai gazdaság és társadalom megmerevedését eredményezte. A bezárkózás miatt Kína nem jutott olyan külső erőforrásokhoz - pedig ereje lett volna hozzá -, melyekkel városai jelentős kereskedelmi tőkét halmozhattak volna fel, és a már régen meglévő fejlett kézmüiparra támaszkodva az iparosodás útjára léphetett volna. $\mathrm{E}$ bezárkózást azután a 19. század második felében a nyugat-európai terjeszkedés törte fel, és indította el kívülről, a kínai szuverenitást csorbítva, az ipari modernizációt.

A harmadik sajátosság, mely napjainkig érvényes, hogy mint említettük a városi társadalomban nem volt európai értelmủ városi polgár, nem volt városi autonómia s ezzel az államszocializmus központosított város irányítása könnyen illeszkedett az évezredes hagyományokhoz, a szovjet államszocialista modellt könnyü volt „kínaira” szabni.

\section{A modern urbanizáció kezdetei}

A modern urbanizáció első fázisa Kínában a 19. század közepétől számítható. Európától és Észak-Amerikától eltérỏen, ez nem a kínai ipari forradalom, hanem külső, gyarmatosító jellegủ, kereskedelmi behatolás eredménye. Formálisan ez a szakasz az 1842. évi nankingi egyezménnyel kezdődött, amelyet a Brit Birodalom csikart ki. Ennek értelmében a britek megkapták Hong Kong szigetét; kereskedelmi és letelepedési engedélyhez jutottak öt kikötőben (Hangzhou, Amoy (ma Xianmen), Fuzhou, Ningbo és Shanghai). A következő évtizedekben más fejlett, gyarmatosító országok - Franciaország, Egyesült Államok, Németország, Belgium és a 19. század végén Japán - hasonló egyezményeket kötöttek, hasonló jogokhoz jutottak. 1911-ben már kb. 90 egyezményes kikötő volt Kínában, végig az egész tengerparton, de a nagy folyók, föleg a Yang Ce mentén messze behatoltak a szárazföld belsejébe is (egészen Chonging-ig). A 20. század elején már 350 ezer külföldi lakos élt az egyezményes kikötőkben! A városrobbanás fázisa tehát nem a helyi, hanem távoli korábbi ipari forradalmak eredménye volt, amikor a fejlett országok nagyméretủ nyersanyag-import és késztermék-export területeket kerestek expanziójukhoz. Felvevő piacként Kína sokkal jelentősebb volt, mint bármelyik korábbi gyarmat. A kínai birodalom pedig hanyatló állapotában is sokkal erősebb volt annál, hogy India vagy Indonézia módjára gyarmatosítsák (Brunn-Williams 1993, 437-440). 
Az egyezményes kikötők új szervezeti és magatartásbeli formákat vezettek be a kínai társadalomba. A külföldi államoknak átengedett városnegyedeket örök bérletre engedték át (mely annyira volt örök, mint bármi a 20. század folyamán), s e területeken a kínai állam szuverenitása korlátozott volt. $\mathrm{E}$ városrészekben a nyugati jogrendet alkalmazták - az adott külföldi állam konzulja volt a jogalkalmazó nemcsak a külföldiekre, hanem az egyezményes területen lakó, dolgozó, kereskedő kínaiakra vonatkozóan is. Az egyezményes városokban fokozatosan elterjedt a nyugati mintájú adórendszer, közigazgatás, rendfenntartás stb. A „modern idők” fontos gazdasági szigetekben jelentek meg, de az egyezményes városokban sem váltak kizárólagossá, és főleg nem formálták át a kínai társadalmat, nem érintették a városhálózat többségét és a kínai állam hagyományos hatalom-gyakorlási módját.

Elgondolkodtató a modern urbanizáció sajátos kínai geográfiája. A kínai birodalom alapvetően szárazföldi birodalom volt, hosszú tengerpartját peremvidéknek tekintette, és még szuverenitásának meggyengülése idején is e tengerpartra korlátozta a külföldi tőke behatolását és a külföldi modern intézmények bevezetését. Ez - mint késöbb erre visszatérünk - megismétlödött a szocialista Kina Mao utáni első gazdasági reform-hulláma idején: egyes tengerparti városokban különleges övezeteket jelöltek ki a külföldi tőke és a kapitalizmus befogadására, ezúttal persze a kínai szuverenitás teljes megőrzése mellett. A piaci reform jelenlegi, a kínai gazdaságot a globális gazdaságba beépító látványos szakaszában is kitüntetett szerep jut a tengerpartnak, Hong Kongtól Sanghájig. A kínai civilizáció lassan, óvatosan, endogén fejlődésének feladása nélkül próbálja beépíteni a fejlett kapitalizmus technikai, szervezeti elemeit a maga szuverén évezredes rendszerébe: a technika gyors átvétele mellett megkísérlik a társadalmi viszonyok, értékrendek, kormányzási formák folyamatosságát fenntartani. Ez a ,gazdasági modernizálás óvatos és korlátozott társadalmi reform mellett" koncepció alkalmasint abban is kifejezödött, hogy a modern elemeket földrajzi szempontból is szelektáltan, föleg a hagyományosan peremvidék-jellegủ tengerparti városokba engedték be első renden. Eközben persze a korábbi peremvidék a gazdasági modernizálás és növekedés, Kína világgazdasági kapcsolatrendszerének fö tengelyévé alakul. Az már a távoli jövő kérdése, hogy a globális gazdaságban egyre nagyobb szerepet játszó Kína ősi civilizációja milyen lényegi módosulást mutat fel.

\section{A szocialista Kina városfejlödése}

A modern urbanizáció eme első, 19. század végi-20. század eleji megjelenése torzó maradt. A hagyományos kínai birodalom válságról válságra bukdácsolt; a császárság forma szerint 1912-ben szünt meg és jött létre a Kínai Köztársaság. Ezután Kína történelme a polgárháborúk, külső (japán) támadások pusztító láncolata, míg 1949-ben győz a Mao-Ce Tung vezette kínai forradalom, kikiáltják a Kínai Népköztársaságot. A szocialista Kína csaknem hatvan éves történetében megkülönböztethetjük Mao-Ce Tung korszakát (1949-1976) és az azóta eltelt, piaci reform- 
Tér és Társadalom 21. évf. 2007/4. 1-20. p.

szocializmusnak nevezhetỏ korszakot. A két korszak államhatalmi-irányítási rendszere folytonosságot mutat, megfelel az államszocialista rendszer alapvető jellegzetességének: az egypárt-rendszernek, a kommunista párt a közigazgatás fölé emelt totális irányító hatalmának; a különbség a gazdaság tulajdoni viszonyaiban, a gazdaság irányításában, a gazdasági szereplők társadalmi rétegződésében van. Az urbanizáció nyelvére lefordítva, a városi kormányzás lényegében folyamatosságot mutat (szervezetében, nem módszereiben), a város-gazdaság, a városnövekedés mechanizmusa, a városi társadalom belsỏ szerkezete a reform 25 éve alatt állandóan módosuló, a klasszikus Mao-i modelltỏl egyre távolodó.

\section{Mao-Ce Tung korszaka}

A kínai forradalom több mint húsz éves partizánháború után győzedelmeskedett. A forradalmi csapatok részt vettek a Japán elleni védelmi háborúban, 1945-1949 között pedig a hivatalos kínai kormány - a Kuomintang kormány - ellen harcoltak. A legyőzött hivatalos hadsereg maradványai menekültek végül is Tajvanra. A kínai forradalmat támogatta a Szovjetunió, és a győztes forradalom intézményi berendezkedése szovjet mintát követett, ám fontos különbségekkel. A kínai forradalom alapjában a városok ellen irányuló parasztfelkelés volt, a csekély méretủ munkásságra aligha támaszkodhattak. Fontos elem volt a népi hadsereg erős kapcsolata a parasztsággal; ennek is köszönhető a rendkívül lerombolt gazdaság gyors és viszonylag kevés áldozattal járó újjáépítése (1952-ben már elérték a háború előtti gazdasági színvonalat). Az erỏs központosított államnak történő engedelmesség megfelelt a kínai hagyományoknak; az újjáépítés, a gyors iparosítás, a foglalkoztatás bövítése, alapvetỏ szolgáltatások általános elterjesztése indokolhatta az erős központosítást, a tervutasításos gazdaságirányítás bevezetését.

A városok fejlesztése is betagozódott a központi tervezésbe (a területi tervezés részeként). Megkülönböztettek „termelö”(=iparral rendelkezö) és „,fogyasztó” városokat. Az iparosítás során az ipar elhelyezésében fontos szempont volt, hogy ezzel minél több fogyasztó várost termelö várossá alakítsanak át. A faluról városba történő vándorlás és a városi népességnövekedés ellenőrzése fontos tervezési módszer volt - ezt késöbb részletesebben ismertetjük. Ez a központi tervezés olyan szempontból eredményes volt, hogy a városnövekedés fékezett volt, a városokban nem halmozódtak fel faluról elmenekült, ám a városokban felesleges, megélhetéshez alig jutó tömegek, mely oly jellemző jelenség a fejlődő országok nagyvárosaiban; végül az ipar (a modern gazdaság) szétteritése a városhálózatban elösegítette a hagyományosan kialakult városhálózat teljes körü modernizálását. A központi tervezés szerény alapellátást biztosított a városlakóknak, a társadalmi egyenlötlenségek mérsékeltek voltak, sikerült biztosítani a közel teljes foglalkoztatást - aminek súlyos társadalmi ára is volt. A városokból kitelepítették a munkahellyel nem rendelkezöket, a kulturális forradalom (1966-1976) idején pedig milliókat kényszerítettek erőszakkal falura (értelmiségieket, osztályidegeneket, friss diplomásokat) ,átnevelésre” a városi 
társadalom munkás-jellegének erősítésére. A szegénység és az éhínség nem tünt el Kínából, ám ezt falura zárták, a városok életszínvonala - a helyi körülményeknek megfelelően - elfogadható volt. A Mao-i szocializmus katasztrofális következményekkel járt a gazdaságra, a sokat kibíró kínai társadalomban is óriási feszültségeket keltett. Mao-Ce Tung halála után a pragmatikusabb pártvezetés mindenekelőtt az élelmiszertermelés növelését, általában a gazdaság erősítését és a hatalmi erőszak mérséklését tủzte ki célul (Brunn-Williams 1993).

\section{A piaci reformok kora (1976-)}

Az elmúlt bő három évtizedben, Kínában a piaci reformok egész sorát hajtották végre anélkül, hogy a politikai rendszerben elmozdultak volna az államszocialista egypártrendszer mindent ellenőrző/irányító modelljétől. Jól ismert, hogy e reformok tartósan rendkívül gyors - a GDP évi 10\% feletti - gazdasági növekedést eredményeztek. Kína felzárkózása a világ vezetô gazdasági hatalmaihoz jelentös, feldolgozóiparának számos ágazata a világtermelés élvonalába került. A rohamos gazdasági átalakulás következtében Kínában a modern urbanizáció mindegyik szakasza egyidejủleg van jelen - a városok egy része még csak most mutatja az ipari elrugaszkodást követő városrobbanás (gyors népességnövekedés) jegyeit, más részükben a szuburbanizáció erősödik, kijelölhetök a városi funkciók kiterjedt város-régiókba való szétterülésének jegyei, megtalálható a poszt-indusztriális, globális hálózatokba illeszkedő, sőt globális irányító szerepeket ellátó városok köre is. A piaci reformok minden lépése más és más urbanizációs hatást váltott ki, ám a mai napig megmaradt a városnövekedés állami szabályozása, a városhálózat tervszerú és arányos fejlesztésére való törekvés.

A Deng Xiaoping nevéhez-korszakához kötődő reformok sora falun kezdődött 1978-ban (a kommunák óvatos felváltása a magán-mezỏgazdasággal), ami az elsó rendủ feszültség forrást, az élelmiszerhiányt mérsékelte. A következő lépés a városi gazdaságban - föleg a szolgáltatásokban, kisiparban - is lehetôvé tette a magángazdaságot. A szolgáltatások fejlödése is sokat javított a városi életkörülményeken, de az első két reformlépés még kevéssé befolyásolta a városhálózat átalakulását. Roppant fontosságú volt a külföldi tớke beengedése, a Mao-i önerőre támaszkodás elvének feladása. A külföldi tőke kiemelkedő szerepủ a gyors gazdasági növekedésben és a városhálózat átalakításában is. A piacnyitás elsőnek a különleges gazdasági övezetekben, föleg a Hong Kong és Shangháj közötti tengerparti városokban történt meg (Nyitott Kapuk Politikája 1979-től). A 20-21. század modern gazdaságát fejlesztő külföldi tőkke megjelenése szinte azonos geográfiájú, mint a 19. századi külföldi tökebehatolás a koncessziós területekre, amely a modern gazdasági fejlödést elindította. Lényeges különbség azonban, hogy a jelen piacnyitást a kínai állam kezdeményezte, és folyamatosan ellenőrzése alatt tartja. Ismét egy modernizációs fázis, amelyik a korábban periférikus - tengerparti - urbanizációs zónát erősíti, jelentős egyenlötlenségeket keltve a tengerparti és a nyugat-kínai városok között. 
Tér és Társadalom 21. évf. 2007/4. 1-20. p.

A gazdasági reform, a piacgazdaság kiépítése nem privatizált, az állami (szövetkezeti) tulajdon megmaradt. A magán mezőgazdálkodás is bérelt földön folyik. A földtulajdon hiánya korlátozza a mezőgazdaság modernizálódását, alacsony a termelékenység, ám ez, a túlfoglalkoztatással mérsékeli az amúgy is jelentős mezőgazdasági túlnépesedést, a falusi munkaerő-felesleget. A magántőke új termelő vagy szolgáltató kapacitásokat hozott létre, így vált a gazdasági növekedés motorjává. A külső piacnyitás után először a külföldi (hong kongi, tajvani) kínai tőke merészkedett be; ma már Kína a világ egyik legielentősebb tőke-importőre, évi 40-45 milliárd dollár külföldi tökebefektetéssel. A világ valamennyi erős gazdasága részt kíván venni a kínai konjunktúrában.

A városnövekedés. A gazdasági növekedés mindenekelött városokhoz kötődik, ennek következtében a falu/város dichotomia erősödött a piaci reformkorszakban. A fö különbség nem a jövedelmek - amúgy jelentỏsen eltérỏ - színvonala, hanem a foglalkoztatás különbsége, továbbá az állami közszolgáltatások szinte kizárólagos városi jellege. A városnövekedés két sajátos elemét vázoljuk itt röviden: a) a nagyvárosi régiók kialakulását és b) a nagyvárosi növekedés állami tervezését és ellenőrzését.

a) A nagyvárosi régiók kiformálódása korunk egyik urbanizációs sajátossága, a nagyvárosi agglomerációk helyére lépnek. A nagyvárosi agglomerációk funkcionális kapcsolatai egyszerüek: a központi városban összpontosulnak a munkahelyek, a városi szolgáltató intézmények, a hozzátapadó elővárosok szerepe, hogy a városban dolgozók egy részének lakóhelyéül szolgáljanak, esetenként a várost speciális kertészeti termékekkel ellássák, a városlakók üdülőhelyei legyenek. A modern nagyvárosi régiók több-központúak, az egy vagy több nagyvárost kis- és középvárosok, falvak egészítik ki, melyek maguk is önálló, más településeket is vonzó funkciókkal rendelkeznek, ezért a munkába járási, szolgáltatási kapcsolatok sokirányúak, átszövik az egész nagyvárosi régiót, nemcsak az elővárosokból ingáznak a nagyvárosi munkahelyekre, hanem a nagyvárosi lakók is kijárnak más települések munkahelyeire, oktatási intézményeibe; nagy bevásárló központok telepednek a települések közötti forgalmi csomópontokba. Ezeknek a nagyvárosi régióknak ritkán van közös közigazgatása, elhatárolásuk sem egyszerủ, ehhez meg kell határozni, meddig tartanak a nagyvárost és környékét összefüzö funkcionális kapcsolatok (Enyedi 2002).

A nagyvárosi régiók elhatárolása Kínában különösen nehéz. Adatok sem nagyon állnak rendelkezésre, a munkába járási távolságokat korlátozza a gyalogosan és kerékpárral munkába járók nagy aránya és az, hogy a városrégiókba integrált vidéki településekben magas a mezögazdasági népesség aránya. Leman (2004) 53 nagyvárosi régiót határolt el, melyek közé a legalább 1 millió nem-mezögazdasági lakosú városokat és a hozzájuk tartozó megyéket sorolta (1.ábra). E régiók jelentik Kína fő gazdasági erejét: 370 millió lakost tömörítenek (az ország lakosságának 29\%-át), a bruttó hazai termék (GDP) 53\%-át, a nem-mezőgazdasági (feldolgozóipari, építőipari és szolgáltatási) GDP-nek pedig 63\%-át adják. A legnépesebb nagyvárosi régió a shangháji (17 millió lakos), melyet a Beijing-i (14,5 millió), a Guangzhou-i (13,7 millió) és a Chengdu-i (11,5 millió) követ. Tizenegy nagyvárosi régiónak van 
5 és 10 millió közötti nem-mezőgazdasági foglalkozású lakosa, húsznak 2-5 millió közötti. A legnagyobb és legdinamikusabb nagyvárosi régiók zömmel a tengerparton helyezkednek el; úgy tủnik, végleg megszünt a kínai városrendszer befelé fordulása. A tengerparti övezet dinamizmusa is jelzi a jelenlegi gazdasági fellendülés külső kapcsolatait: a külföldi tớke nagy szerepét és az export, a külső piac elsődleges jelentőségét.

\section{1. ÁBRA}

Kina 53 nagyvárosi térsége a nem-mezögazdasági népesség nagysága szerint (2000)

(China's Metropolitan Regions by Size of Non-farming Population [2000])

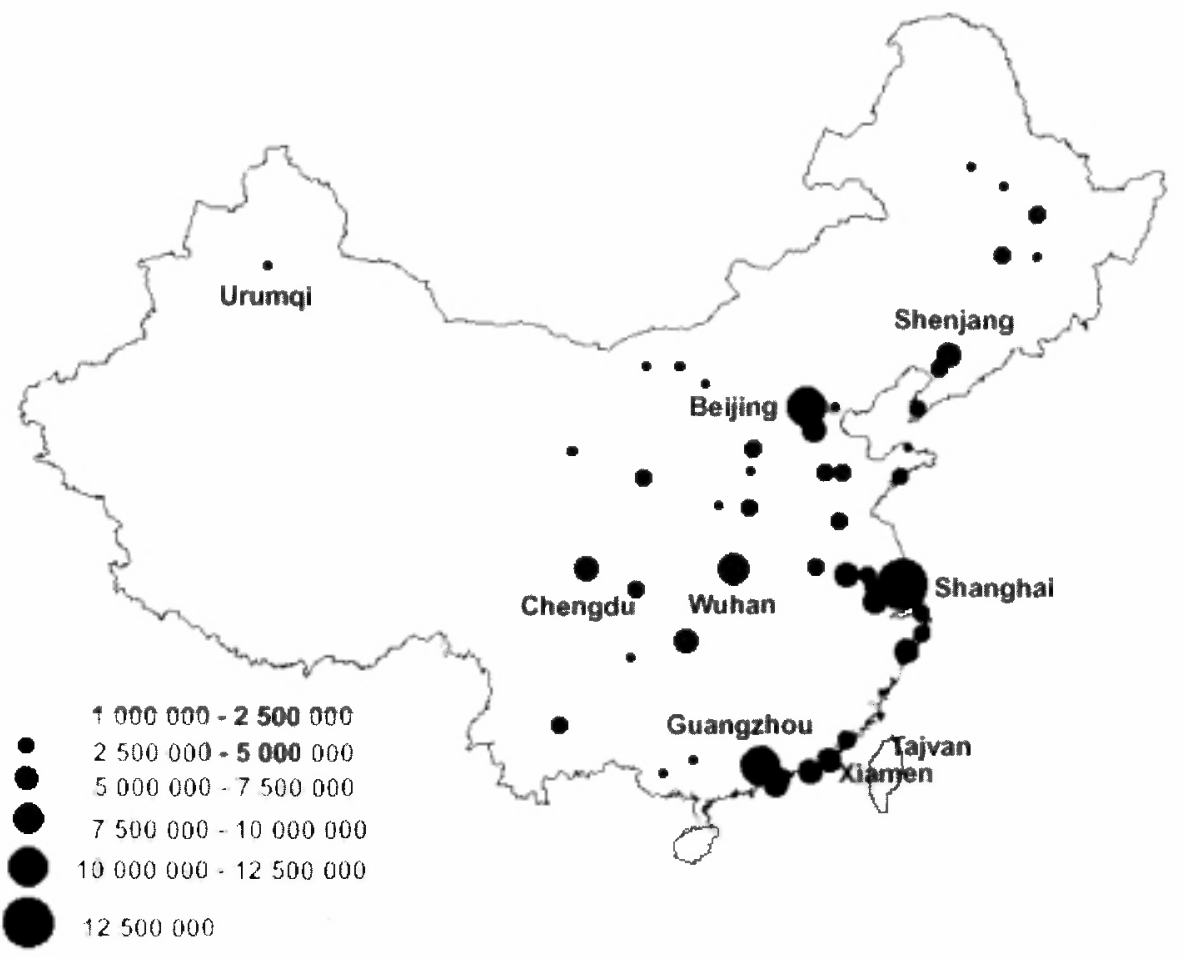

Forrás: Leman $(2004,258)$.

A kínai nagyvárosi régiók különböznek az európai vagy észak-amerikai nagyvárosi régióktól, jóllehet a felületes utazó a felhőkarcolók vagy forgalmi dugók kapcsán először a hasonlóságokra gondol. Ilyen különbség a mezögazdasági népesség már említett magas aránya. Az 53 nagyvárosi régióból csak 15-ben lépi túl a nemmezőgazdasági népesség a 70\%-os arányt. Ezek közül csak egy (Urumqi) van Nyugat-Kínában; egyébként a nyugat- és közép-kínai nagyvárosi régiókban 40-60\%-ot tesz ki a nem-mezőgazdasági foglalkozású népesség. Sajátos volt az első ipartelepítési hullámban létrehozott ipari kombinátok helyzete, melyekhez lakótelepeket és 
Tér és Társadalom 21. évf. 2007/4. 1-20. p.

alapszolgáltató intézményeket is építettek, így nem indítottak el jelentős ingavándorlást. A gazdaság agglomerációs elönyei kevés helyen mutatkoznak; alacsony a munka termelékenysége, korszerủ, innovatív ipar is csak néhány vezetô városrégióban múködik. A kínai városi agglomerációk $\mathrm{K}+\mathrm{F}$ szektora gyengén fejlett, a munkaerő szakképzettsége is elégtelen, a versenyképesség alacsony bérköltségeken, tömegtermékek rutinszerủ gyártásán alapul. Ez természetesen változik, növekszik pl. a felsőoktatásban résztvevők száma, és figyelembe véve a hatalmas munkaerőbázist, nem hisszük, hogy a technológiai és munkatermelékenységi verseny elsőrendü fontosságú a mai Kínában. Napjaink kapitalizmusának egyik ellentmondása, hogy olyan technológiai fejlesztésekre koncentrál, amelyek munkaerőt takarítanak meg (pedig a bőséges munkaerőforrás ezt nem indokolja), és e technológiai fejlesztésekbe rengeteg tőkét invesztál (amelyben a Föld legtöbb országa szükölködik). Ez a fajta fejlődés-felfogás is hozzájárul az országok közötti és országokon belüli társadalmi egyenlőtlenségek növekedéséhez, tömegek kirekesztéséhez a munkaeröpiacról. Nem bizonyos, hogy a nagy népességü feltörekvő gazdaságoknak - mint az indiai és a kínai - is ezt az utat kell követni, ám az sem bizonyos, hogy a felzárkózási pályán követhetnek-e mást?

b) A városnövekedés irányítása. A gyors városi/nagyvárosi gazdasági növekedés, a falu/város dichotomia erősödése, a mezőgazdasági túlnépesedés hatalmas vándorló tömegeket zúdít a városokra a fejlödő országokban, $\mathrm{s}$ a legtöbb Európán kívüli feltörekvő gazdaságban is. Az állandó foglalkoztatáshoz nem jutó falusi bevándorlók tömegei összeroppanthatják a város kormányozhatóságát, társadalmi békéjét és fejlödését. Sok helyütt próbálkoznak a bevándorlás adminisztrativ korlátozásával, általában kevés sikerrel. Kínában a háztartások regisztrációja (a hukou rendszer) szolgál a vándorlások ellenörzésének, az anarchikus városnövekedés korlátozásának eszközéül.

Hivatalosan a regisztráció az állampolgárok nyilvántartását szolgálja, állandó lakhelye szerint és az ideiglenesen felkeresett település szerint; a regisztrációt elrendelö törvényt 1958-ban hozták; 1985-ben vezették be a személyi igazolványokat. Az állampolgárok személyi adatainak és lakhely-változtatásának regisztrációja a modern államokban általános; minden európai országban van valamilyen személyi igazolvány, bejelentó lapokat kell kitölteni a szállodákban stb. A közszolgálttatások müködtetéséhez mindenütt szükséges a népesség nyilvántartása; a kínai hukou rendszer is évszázados. A lényeges különbség, hogy a mai Kínában lakhelyet - akárcsak ideiglenesen - változtatni csak a hatóság engedélyével lehet, az állampolgároknak nincs szabad mozgása. Ez sem csak kínai sajátosság, a Szovjetunióban sem utazhattak szabadon az állampolgárok - $\mathrm{s}$ a belső útlevelet és vízumot (utazási engedélyt) még a cári Oroszországból örökölték. (Ezzel a városokat védték a szökött jobbágyoktól, meg a Szibériába számüzöttek visszatérését, vagy a közép-ázsiai és Kaukázuson-túli nemzetiségek orosz területre történő bevándorlását igyekeztek megakadályozni).

A regisztrációt a rendőrség végzi, a helyi rendőr-őrszobán kell bejelentkezni, és mindenkinek csak az örszoba hukou-zónájában lehet állandó tartózkodási engedélye (lakhelye). A regisztrációkat a felettes állambiztonsági szervek és a helyi pártbizott- 
ságok ellenőrzik. A regisztráció egysége a háztartás, mely lehet család, egyetlen személy, vagy „kollektív háztartás”: munkabrigád vagy munkásszállás.

A regisztrációért a háztartás feje felelős: minden változást (születés, halál, házasság) be kell jegyeztetni a rendőr-őrszobán. Minden lakóhely-változtatáshoz rendőrségi engedély kell: városon belül is, bár ez csak adminisztrativ formaság. A faluról városba történỏ költözés engedélyezése bonyolultabb: ez általában csak ideiglenes vándorlási engedély, városi állás-igazolás vagy városi tanintézeti-felvételi igazolás kell hozzá, esetleg a városi bevándorlás speciális engedélye (párt- és állami káderek részére). A határövezetbe való bevándorláshoz felsőbb (megyei, tartományi) állambiztonsági engedély kell.

Aki 3 napnál (!) hosszabb időre megy egy másik településbe, ott be kell jelentkeznie ideiglenes lakosnak; a tartózkodási engedély 3 hónapra szól, a megújítási kérelmet indokolni kell.

A hukou rendörség 4 szempontot követ a vándorlások ellenörzésekor (Fei-Ling 2004, 122): 1) szigorúan ellenörzi a faluról városba vándorlást, a mezőgazdasági foglalkozás nem-mezőgazdasági foglalkozásra váltását; a kisvárosból nagyvárosba, a nagyvárosokból a 3 kiemelt városba (Beijing, Shanghai, Tianyin) történő népesség-mozgást; 2) megfelelöen ellenőrzik a falvakból az elövárosokba, elővárosokból városokba, kisvárosból nagyvárosba történő költtözést; 3) nem kell ellenốrizni a hasonló szintủ falvak vagy hasonló szintủ városok közötti vándorlást; 4) bátorítani kell a városokból falvakba, a nagyvárosokból kisvárosokba szétszóródó vándorlást, fóleg tanult emberek esetében.

Elvben az egyetemet végzetteknek vissza kell térni állandó lakóhelyükre; a gyakorlatban a nagyvárosi munkaügyi hivatalok általában engedélyezik nem helyi munkavállalók alkalmazását a helyi foglalkoztatók, föleg külföldi vállalkozások kérésére.

A lakosság vándorlásának ellenőrzése régi hagyomány. A faluról városba történő bevándorlás a Kínai Népköztársaság első (1949-1957) közötti szakaszában még helyenként bátoritást is kapott, az iparosítás munkaerő-igényét kielégítendö. A Nagy Ugrás Elöre programja (1958) olyan gazdasági összeomlást eredményezett, hogy ismét éhínség ütötte fel a fejét, amelytől a városi népességet meg kívánták kímélni. Ezért szigorodott meg 1958-tól a hukou rendszer: a faluról való tömeges elmenekülést megakadályozandó. 1958 után a kínai társadalom kettészakadt: egy kisebbségi, legalább elemi szinten ellátott városi társadalomra és a többségi, magára hagyott, a kommunákban primitív önellátásra kényszerített falusi társadalomra. A két rész-társadalom között alig volt átjárás. A szabad költözés jogát ugyan benne felejtették az alkotmányban, csak 1975-ben törölték. A kulturális forradalom (1966-1976) idején a vándorlás állami kényszerintézkedés volt: 43 millió városlakót „küldtek le” falura fizikai munkát végezni, $\mathrm{s}$ több millió paraszt kapott „nem-mezőgazdasági foglalkozású” regisztrációt a hadseregben, felsőfokú oktatási intézményekben, állami közhivatalokban. 
Tér és Társadalom 21. évf. 2007/4. 1-20. p.

Évente kevés mezőgazdasági (=falusi) regisztráció változtatható meg állandó nem-mezőgazdasági (=városi) regisztrációra. Ennek mértékét (jelenleg évente országosan a mezőgazdasági népesség $0,5 \%$-a lehet) az Országos Tervhivatal szabja meg, s osztja el a tartományok, a tartományi tervezö szervezetek meg az egyes települési hukou rendőri körzetek között. Az engedélyezett létszámhoz a tervezett munkaerő-szükségletet és a városi ellátási lehetőségeket veszik figyelembe.

\section{TÁBLÁZAT}

A teljes népesség és a városi népesség számának alakulása Kinában, 1949-2000

(The Size of the Total and Urban Population in China [1949-2000])

\begin{tabular}{cccc}
\hline Év & $\begin{array}{c}\text { Teljes népesség } \\
(\text { millió fö) }\end{array}$ & $\begin{array}{c}\text { Városi népesség } \\
\text { (millió fö) }\end{array}$ & $\begin{array}{c}\text { Városi népesség- } \\
\text { arány (\%) }\end{array}$ \\
\hline 1949 & 541,67 & 57,63 & 10,64 \\
1960 & 662,07 & 130,76 & 19,75 \\
1970 & 829,92 & 144,24 & 17,38 \\
1980 & 987,05 & 191,39 & 19,39 \\
1990 & 1143,33 & 301,91 & 26,41 \\
2000 & 1265,83 & 458,48 & 36,22 \\
\hline
\end{tabular}

Forrás: Zhang (2002).

$\mathrm{Az}$ állandó városi lakóhellyel rendelkezők rendkívül nagy elönyöket élveznek gyakorlatilag csak ők vehetik igénybe az ingyenes vagy kedvezményes közszolgáltatásokat, az iskolától az egészségügyi ellátásig, a lakáskiutalásig. E közszolgáltatásokra az ideiglenes városi lakóhely regisztrációjával rendelkezők sem tarthatnak igényt (még akkor sem, ha évek óta laknak s dolgoznak a városokban). Az 1990-es évek elejéig az élelmiszer-jegy volt a nagy vándorlási fék: ezt csak állandó városi regisztrációval rendelkezők kapták. Jelenleg a piaci lakbér, az iskolai tandij, vagy a magán egészségügyi ellátás a nagy hátrány. A munkanélküli segélyre is csak az állandó városlakók számíthatnak; gyermekeik alacsonyabb felvételi pontszámmal kerülhetnek be a helyi egyetemekre stb. (Good Kind-West 2004).

Ez a szigorú falu/város elkülönítés nehezen egyeztethető össze a piaci reformokkal; a hukou rendszer módosulóban is van, vannak helyi változatai, de lényegét tekintve ma is müködik. Mennyire sikeres? Vajon mit nevezünk sikernek a települési folyamatokba történő erőszakos beavatkozások esetén? Kétségtelen, hogy a városba vándorlás mértéke korlátozott; a tartós városi gazdasági növekedést visszafogott (állandó) városi népességnövekedés kíséri: végül is legfeljebb $40 \%$ városlakó egy gazdasági nagyhatalom esetén igazán alacsony arány. A központi tervezés megakadályozta a fejlödő országok nagyvárosaira oly jellemző tömeges társadalmi kirekesztỏdést, a hatalmas nyomornegyedek kialakulását. A regisztrációs rendszer első renden a nagyvárosi túlnépesedést korlátozza, a kis- és középvárosokba egyszerübb bevándorolni a falvakból, ezzel a településhálózat arányos fejlesztésére ösztönöz. A falusi túlnépesedés erősen korlátozza a mezőgazdaság technikai fejlödését, a falu elszegényedése - a szegénység falura zárása - a belsỏ piacot nagyon gyengíti, ezért a kínai gazdasági növekedés túlzott mértékben az export - a külső 
piac - függvénye. Közgazdasági és szociális érvek állhatnak egymással szemben; ám ezek az érvek nem mindig veszik figyelembe a háromezer éves kínai urbanizáció endogén jellegét, „nyugati” analógiákat alkalmaznak. Piaci reform és központi tervutasításos rendszer - ez mindenképpen „különös házasság”. Nem is müködhet jól ezt a városban lakó/dolgozó, de állandó falusi lakhelyén regisztrált „bolyongó” " népesség nagy száma bizonyítja (Fei-Ling 2004).

c) A „bolyongó" népesség tényleges számát nehéz megállapítani, hiszen egy részük illegális bevándorló, mások ideiglenes tartózkodási engedéllyel élnekdolgoznak évek óta a városokban. E népesség egyik része idénymunkás, fóleg az épitöiparban, szolgáltatásban dolgoznak, néhány hónap után visszatérnek falujukba (hogy az első adandó alkalommal ismét útra keljenek). Az ideiglenes tartózkodási engedéllyel hosszú ideje ott-tartózkodók remélik, hogy egyszer állandó letelepedési engedélyt kaphatnak. A 2000. évi népszámlálás számukat 64 millió fớben adta meg; az Állambiztonsági Minisztérium azonban 100 milliósra becsüli tömegüket: közülük csak 38 millió fỏnek volt ideiglenes városi tartózkodási engedélye. A tényleges városi népesség mindenesetre jóval nagyobb, mint a regisztrált, és számuk egyre növekszik.

A „bolyongó” népesség 2/3-a fiatal férfi, többnyire szakképzetlen, fóleg a nagy infrastrukturális beruházásoknál jutnak munkához. A család falun marad, hiszen városi szolgáltatásokat nem vehetnek igénybe, lakáshoz nem juthatnak. 1998 óta kötelező a „bolyongó” családok városi alapfokú (6-14 éves korig) iskoláztatása; a városokban többnyire szegregált iskolákban helyezik el öket.

A „bolyongóknak” városi regisztrációt (állandó letelepedési engedélyt) kapni alig lehetséges, a kvóták nagyon szükmarkúak. A képzett munkaerőt igénylő, gyors gazdasági növekedést mutató nagyvárosokban a helyi várospolitika kínálhat közbeeső, a központi kvótától eltéró megoldásokat, fốleg ha a letelepedést kérelmezők tőkebefektetésre is kötelezik magukat, s jó adófizetôknek is bizonyulnak, saját házuk van stb. Az így megszerzett regisztrációért magas dijakat is kell fizetni a városi hatóságoknak, a legtöbbet (40 000 yüan) ${ }^{6}$ a legkapósabb Sanghájban (Chan-Li 1999).

$\mathrm{Az}$ állambiztonsági hatóság visszaküldheti eredeti lakóhelyére a városokban engedély nélkül tartózkodókat. 2000-ben a pekingi rendőrség 350 ezer embert toloncolt ki a városból, akiknek lejárt vagy sohasem volt tartózkodási engedélye. Nagyot fordult a világ: míg Mao-Ce Tung szegény parasztokból rekrutálta a városokra támadó forradalmi hadseregét, ma a falusi Kínát rengeteg hátrány sújtja - a falu/város szakadék enyhítésével csak most kezd foglalkozni a területi tervezés.

A „bolyongó” népességet a munkahelyén sem kényeztetik el, gyakran alacsonyabb bért kap a városlakókénál azonos munkáért, de még ez is magasabb a falusi jövedelmeknél. Rendszeresen küldenek haza megtakarításaikból falusi családjuknak. Chan (2001) szerint ez 2000-ben 150 milliárd yüan volt, jóval több az országos költségvetés teljes mezőgazdasági támogatásánál (115 milliárd yüan).

d) A városhálózat. A városnövekedés tervszerü irányításának köszönhetően a városhálózat méret szerinti megoszlása - a fejlődő országokétól és a feltörekvő piacgazdaságokétól eltérően - arányos, és a gyors gazdasági növekedés sem torzítja el. 
Song és Zhang (2002) a Pareto-egyensúly számítását alkalmazza a városhálózat arányosságának, a rangsor-méret szabály (rank-size rule) érvényesülésének mérésére. ${ }^{7}$ Ennek eredményeként megállapították, hogy a városhálózat 1985 és 2000 között jelentősen kiterjedt, ám ez nem járt együtt a legnagyobb városok gyors kiemelkedésével, sőt a hálózat kiegyenlítettebb lett. $\mathrm{A}$ legnépesebb város a teljes városi népesség 4,87\%-át tette ki 1985 -ben, 4,08\%-át 2000-ben. A tíz legnépesebb város aránya pedig $23,76 \%$-ról 19,37\%-ra csökkent a fenti idöszakban. A városhálózat kiegyenlítődése csak a legfejlettebb országokban mutatkozik, jóval lassúbb gazdasági növekedés, csekély népességgyarapodás, söt többnyire általános népességfogyás, alacsony falusi népességarány mellett. Kína egyedi eset: az államszocialista piacgazdálkodás esete, ahol mind a falu-város vándorlás, mind a külföldi müködötőke befektetés telephely választása központilag szabályozott. A kormányzati várospolitika a kis- és középvárosi növekedést támogatja. Az arányos városhálózatnak azonban társadalmi ára van: a falusi túlnépesedés, a városok gazdasági fejlődésének adminisztratív - nem hatékony - irányítása. Óhatatlanul felmerül a kérdés: meddig mủködhet együttélésben az államszocialista rendszer és a piacgazdaság?

\section{Összefoglalás}

A tanulmány záró fejezetében az eddigieket összegezve két kérdésre keresünk választ: 1) melyek a sajátos jellemzöi a kínai urbanizációnak, amelyek alapján endogénnek - tehát nem modell-követỏnek, nem modell-értékünek - minősíthetjük? 2) Az elöre jelezhetö gazdasági növekedés és városnövekedés milyen konfliktusokat, változásokat hozhat középtávon?

A kínai urbanizáció egyedülállósága nemcsak a jelen szakaszra jellemzö, hanem egész, több ezer éves történetére. Ez csak azzal magyarázható, hogy a kínai gazdaság és társadalom fejlödése külsö hatásoktól elzárva, endogén módon folyt a közeli múltig (a 19. század végi modernizáció kezdetéig), és e fejlődést más földtulajdon viszonyok, más földhasználati formák, más államszervezési keretek stb. jellemezték, mint az antik vagy középkori Európát. Ez a különállás egész Ázsiára jellemzö volt ${ }^{8}$, ám a gyarmatosító behatolás a hagyományos társadalmi szervezeteket, köztük a települési szervezỏdést is széttörte. Kína azonban, mint már említettük a 19. század végi európai-amerikai behatolást területileg is (a koncessziós városokra), az állam múködésére vonatkozóan is korlátozni tudta. Az is kiderült, hogy az államszocialista rendszer eddigi pályáján - benne a város-müködésben - sem került sor a - csak rövid ideig követendőnek tartott - szovjet modell másolására.

A sajátos „kínai út” ma is érvényesül. A piaci reform - melyet fokozatosan vezettek be - látványos gazdasági növekedést eredményezett, de nem érintette a kommunista egypárt-rendszert, a központi állam mindent szabályozó szerepét, az állam, a „birodalom” feltétlen tekintélyét. A látványos külföldi tökebefektetések és a gyarapodó hazai tőke ellenére az állami tulajdon nagy jelentőségü: kiterjed az egész mezőgazdasági területre, a hagyományos bányászati-nehézipari ágazatokra; azután - 
föleg vidéken - elterjedtek a köztes - sem nem magán, sem nem állami, az egykori magyar kisipari termelőszövetkezetekre hasonlító - tulajdonformák. Az ilyen vállalatok vezetőit a helyi pártszervezetek nevezik ki, de nyereségérdekeltek.

A helyi, tartományi kormányzatok hagyományos lojalitása lehetővé teszi, hogy a politikailag centralizált pártállamban a forráselosztás decentralizált legyen: 2003-ban a bruttó hazai termék 13\%-át tette ki a központi költségvetési kiadás (Csaba 2006, 378), ami roppant alacsony arány.

A kínai urbanizáció tehát ma sem modell-követö: a városnövekedés korlátozott, a falusi népességet lassan, fokozatosan „vezetik át” a városi foglalkozásokba. Ennek következménye a súlyos falusi túlnépesedés, a mezőgazdaság alacsony termelékenysége, a falusi szegénység - mely tízmillió számra löki ki és teszi illegális városlakóvá a bolyongó népességet. A rendkívül nagy települési és regionális egyenlötlenségek a 2007. októberi pártkongresszust is erỏsen foglalkoztatták, és elhatározták a vidék infrastrukturális fejlesztését, a munkaalkalmak bővítését (erre lehetőséget ad a nagy költségvetési többlet). A falusi népesség foglalkozási átrétegződése még középtávon biztosíthatja a gyors gazdasági növekedést.

És azutản? Stabil lehet-e hosszú távon egy szocialista piacgazdaság? Az eddigi tapasztalatok szerint nem. Megmaradhat-e a kínai urbanizáció endogén jellege a globalizáció korában, amikor nem rekeszthetők ki oly mértékben a külső hatások, illetve nem illeszthetók oly egyszerúen be a kínai hagyományokba, mint az évezredekig sikerült? Ảltalános vélemény szerint aligha - de hát a jövőról nincs tapasztalatunk. A kínai történelem korábbi menete sem felelt meg az európai tapasztalatoknak. Jóslás helyett elcsenjük Rostow (1960) „,bon mot”-ját: nem foglalkozom előrejelzéssel, különösen a jövőre vonatkozóan nem...

\section{Jegyzetek}

${ }^{1}$ A városi népesség számára s arányára vonatkozóan eltérỏ adatokkal találkozunk a hivatalos forrásokban is, attól fưggően, hogy a népszámlálás jelenlévő népességét, a regisztrált városlakókat vagy a regisztrált és tartózkodási engedéllyel rendelkezóket veszik-e figyelembe. Az adatok 32 és $40 \%$ között mozognak. A kínai földrajzi nevek írásánál a hivatalos (és nem a magyaros) átírást alkalmaztuk.

${ }^{2} \mathrm{Az}$ antik Rómának a 2. században 2 millió lakosa volt; ezt a lélekszámot európai nagyváros csak a 19. század közepén érte el ismét (ez London volt).

${ }^{3}$ Elvin (1977) a mezögazdaság középkori társadalmi szervezetét „majorsági rendszer feudalizmus nélkül'-nek nevezi.

${ }^{4}$ A Han-korban vezették be a hivatalnoki vizsgarendszert, amelyen a jelölteknek a konfuciánus Öt kanonikus müből kellett vizsgát tenniük, s azután nyerhettek el hivatalnoki állást.

${ }^{5}$ Az angol szakkifejezés „floating population” (kínai: lindong renkou), talán a „bolyongó" megnevezés jól jellemzi, hogy e vándorlók regisztrált falusi lakhelyük és a foglalkozást nyújtó városok között rendszertelenül ide-oda vándorolnak.

${ }^{6} 1$ USD $=8,28$ yüan (hivatalos átváltás) ill. 1,78 (!) vásárlóerö-paritáson számolva.

${ }^{7}$ A városok térbeli eloszlásának szabályossága már régen foglalkoztatja a geográfusokat. B. J. L Berry (1961) a világ számos országára elvégzett vizsgálata - melynek során regressziós analízis módszerrel hasonlította össze a gazdasági fejlettség és a városok méret szerinti térbeli összefüggéseit - a következö fö eredményeket hozta: 1) a teljes városhierarchia csak fejlett, nagy területủ és népességü országokban alakul ki arányosan; 2) kisterületü fejlett országokban vagy van egy nagyváros és hiányzik az erös középváros (Portugália, Görögország, Dánia, Magyarország), vagy erős középvárosok vannak nagyváros 
nélkul (Svájc, Hollandia). A feltörekvő és elmaradott országokban a városhierarchia torz, a legnagyobb város aránytalanul kiemelkedik, egyes középvárosi kategóriák hiányoznak, vannak városhiányos területek. Látnivaló, hogy Kína nem illik ebbe a képbe.

${ }^{8}$ 1. Tỏkei (1965) kitủnỏ elemzését.

\section{Irodalom}

Antier, G. (2007) Masses urbaines en Chine et en Inde (1980-2020). - La Géographie. 1526. 10-21. o.

Balazs, E. (1964) Chinese Civilization and Bureaucracy. CT: Yale University Press, New Haven.

Berry, B.J.L. (1961) City size distribution and economic development. - Economic Development and Cultural Change. 9. 263-282. o.

Brunn, S.D.-Williams, J.F. (eds.) (1993) Cities of the World: World Regional Urban Development. Harper Collins, New York.

Chan, K. (2001) Recent migration in China: patterns, trends and policies. - Asian Perspective. 4. 127-155. o.

Chan, K.-Li, Z. (1999) The Hukou system and rural-urban migration in China: processes and changes. The China Quarterly. 160.818-855. o.

Csaba L. (2006) A fölemelkedó Európa. Akadémiai Kiadó, Budapest.

Eisenstadt, S.N.-Shachar, A. (1983) Society, Culture and urbanization. SAGE Publ., Newbury Park, Beverly Hills, London, New Delhi.

Elvin M. (1977) Fejlödés és stagnálás a kinai történelemben. Kossuth Kiadó, Budapest.

Enyedi Gy. (2002) Nagyvárosi régiók. - Az ötven éves Nagy-Budapest: elözmények és megvalósulás. Tanulmányok Budapest múltjából. XXX. Budapest Főváros Levéltára, Budapest. 9-27. o.

Fei-Ling, W. (2004) Hukou Systems and migrations controls. - Chen, A.-Lin, G.G.-Zhang, K.H. (eds.) Urban Transformation in China. Ashgate, Aldershot. 118-137. o.

Gernet J. (2005) A kinai civilizáció története. Osiris, Budapest.

Good Kind, R.-West, L.A. (2004) Floating population: definitions, data and recent findings. - Chen, A.Lin, G.G.-Zhange, K.H. (eds.) Urban Transformation in China. Ashgate, Aldershot. $118-132$. o.

Jordán Gy.-Tálas B. (2005) Kina a modernizáció útján a XIX-XX. században. Napvilág, Budapest.

Leman, E. (2004) Metropolitan regions: New challenges for an urbanising China. - Ekistics. 427. 255-282. o.

Mote, F.W. (1977) The transformation of Nanking, 1350-1400. - Skinner, G.W. (ed.) The City in Late Imperial China. CA: Stanford University Press, Stanford.

Rostow, W.W. (1960) The Stages of Economic Growth. M. I. T. Press, Cambridge.

Shuanling, L.-Shunfeng, S. (2002) Urban Economic Growth in China: Theory and Evidence - Urban Studies. 12. 2251-2266. o.

Song, Sh.-Zhang, H. (2002) Urtanization and city size distribution in China. - Urban Studies. 12. 2317-2327. o.

Tökei F. (1965) Az ,ázsiai termelési mód" kérdéséhez. Kossuth Kiadó, Budapest.

Zhang, K.H. (2002) What explains China's rising urbanization in the Reform Era. - Urban Studies. 12. 2301-2315. 0 .

\section{THE CHINESE CITY}

\section{GYÖRGY ENYEDI}

The rapid growth and the succesful catching up of the Chinese economy as well as its spectacular impacts on urban growth (sixty cities have of over 1 million inhabitants) attract a great interest worldwide. In this paper, we are looking an answer for the following question: how this urban development is an endogenous process, based on the long run trajectory of Chinese urbanisation and how it reflects / follows the general patterns of recent globalised urban development?

We concluded that Chinese urbanisation has always been unique. Here are a few evidences: a) Chinese urbanisation has been the only uninterrupted, continous one all over the world since over 3000 years; b) the economic functions of the cities, their social structure and social organisation, urban land use and urban planning as well as urban 
governance has always been differerent to any other urban zone of the world; c) recent, market-led urbanisation has been unique so far, as the urban growth has been strictly controlled by the government (the share of urban population is still but $35-40 \%$ to the total one); there is a specific regulation of rural to urban migration; the clear evidence of the ranksize rule within the urban system, what is non-existent in any other third world or emerging economies. Overpopulation and poverty has been kept back in the countryside - which, in long run could lead to important socio-economic conflicts. 